\title{
Optimization of Reporting Regulations to Measure Regional Development Performance
}

\author{
Titut Amalia \\ \{titutamalia@yahoo.com\} \\ Diponegoro University, Jl.Prof. H. Soedarto, S.H. Tembalang, Tembalang, Kota Semarang, Jawa \\ Tengah, 50275, Indonesia
}

\begin{abstract}
Successful implementation of development requires a measurement. Measurements are performed both during the process of monitoring and evaluation. Currently, there are several laws and regulations mandated to conduct monitoring and evaluation of the implementation process of regional development. The regulations are mandated in the form of different laws and regulations but with almost identical mechanisms and substances. This requires so much time and money in the implementation. Through proper research methods of Juridical Normative, this paper will try to explore and to analyze various efforts. One of them is to unify the regulations among any other ways. It is necessary that reporting regulations of regional development performance can be empowered and capable. So that the measurement of development performance obtained through monitoring and evaluation of development implementation can optimally use for future improvement of regional development planning.
\end{abstract}

Keywords: Monitoring and Evaluation, Regional Development Program, Reporting Regulation

\section{Introduction}

Development as a form of effort in improving the life of a better society before is a series of interconnected cycles that begins with development planning and ends with the implementation of monitoring and evaluation [1]. All agencies conduct supervision and evaluation by the duties and functions of each agency in development. It aims to realize the purpose of development of the Indonesian Nation listed in the Preamble to the 1945 Constitution.

According to Sjafrizal [2], evaluation of the implementation of regional development in general aims to find out how far the implementation of development carried out. Based on the evaluation results, the implementation of such development will be able to obtain input to improve the preparation of plans. Development monitoring and evaluation are conducted by both central and local government agencies, and implemented according to prevailing laws and regulations and outlined in the form of performance reports with various types of reports.

Currently, there are several laws and regulations governing the implementation of development monitoring and evaluation that vary from the level of Law, Government Regulation to Ministerial Regulation. The monitoring and evaluation are conducted at the same time. Purpose, utilization, and implemented at the same time, of course, require energy and cost that are not small. Facts in the field show that monitoring and evaluation of a similar activity can sometimes be repeated over time. This, of course, resulted in the energy released both from technical and non-technical aspects to be inefficient. This, of course, needs to get 
repaired. Therefore, this study will analyze the legislation that regulates the reporting of development performance at the provincial and district/city level. The discussion covers the form of arrangements on monitoring and evaluation of regional development planning in legislation and realizing the unification of legislation on the monitoring and evaluation of regional development planning. In line with Ansell opinion which stated that the emergence of networked polity in the field of regional economic development must be seen first in light of macrohistorical shifts in the role of the national state in regional development [8].

\section{Methodology}

This research is research using non-doctrinal approach. According to SoetandyoWignjosoebroto [3], the social and empirical non-doctrinal research will produce theories about the existence and function of law in society and the changes that occur in the process of social change. The study also uses primary, secondary, and tertiary materials. Analysis of the various laws and regulations which are then associated with the opinions of the executors [4].

\section{Findings}

Development, according to Adon Nasrullah Jamaluddin, [5] is a form of effort either to promote or to improve and to increase the value of something that already exists. Development begins with development planning. Development planning that has been prepared for subsequent implementation as planned. Implementation of development is filled with the dynamics of both the progress and constraints that need to be arrested and monitored periodically. As the purpose of the evaluation of the implementation of regional development, in general, is to find out how far the development plans that have been prepared and established by authorized officials can be implemented in practice. In line with RodriguezPose opinion which stated that the influence of institutions on regional development patterns was fundamentally neglected by mainstream economic theory which tended to assume instead that utility-maximizing individuals satisfying individual preferences would result in efficient and socially optimal outcomes [10].

Regulations governing the implementation of monitoring and evaluation carried out by the Regional Government are listed in table 1.

Table 1.Legislation Regulation Field Monitoring and Evaluation of Regional Development

\begin{tabular}{|c|c|c|c|c|c|c|}
\hline Rules & $\begin{array}{l}\text { Original } \\
\text { Mandate }\end{array}$ & $\begin{array}{l}\text { Reporting } \\
\text { Objective }\end{array}$ & $\begin{array}{l}\text { Subject } \\
\text { Objective }\end{array}$ & Timing & User & Indicator \\
\hline $\begin{array}{l}\text { Government } \\
\text { Regulation } \\
\text { Number } 39 \\
\text { the Year } \\
2006 \text { on } \\
\text { Procedures } \\
\text { for Control } \\
\text { and } \\
\text { Evaluation } \\
\text { of the }\end{array}$ & $\begin{array}{l}\text { Act Number } 25 \\
\text { the Year } 2004 \\
\text { regarding } \\
\text { National } \\
\text { Development } \\
\text { Planning } \\
\text { System }\end{array}$ & $\begin{array}{l}\text { For the } \\
\text { preparation } \\
\text { of National / } \\
\text { Regional } \\
\text { development } \\
\text { plans for } \\
\text { Next period }\end{array}$ & $\begin{array}{l}\text { Ministries / } \\
\text { Institutions (K / } \\
\text { L) and Regional } \\
\text { Organizations } \\
\text { (OPD) }\end{array}$ & Quarterly & $\begin{array}{l}\text { Ministries / } \\
\text { Institutions } \\
(\mathrm{K} / \mathrm{L}) \text { and } \\
\text { Regional } \\
\text { Organization } \\
\mathrm{s} \text { (OPD) }\end{array}$ & $\begin{array}{l}\text { K / L: } \\
\text { Programs / } \\
\text { Activities } \\
\text { Regional } \\
\text { OPD: Co- } \\
\text { Administrati } \\
\text { on and } \\
\text { Deconcentra } \\
\text { tion }\end{array}$ \\
\hline
\end{tabular}




\begin{tabular}{|c|c|c|c|c|c|c|}
\hline Rules & $\begin{array}{l}\text { Original } \\
\text { Mandate }\end{array}$ & $\begin{array}{l}\text { Reporting } \\
\text { Objective }\end{array}$ & $\begin{array}{l}\text { Subject } \\
\text { Objective }\end{array}$ & Timing & User & Indicator \\
\hline \multicolumn{7}{|l|}{$\begin{array}{l}\text { Implementati } \\
\text { on of } \\
\text { Developmen } \\
\text { t Plans }\end{array}$} \\
\hline $\begin{array}{l}\text { Government } \\
\text { Regulation } \\
\text { Number } 3 \\
\text { the Year } \\
2007 \\
\text { Concerning } \\
\text { the Report } \\
\text { on the } \\
\text { Implementati } \\
\text { on of Local } \\
\text { Government } \\
\text { to the } \\
\text { Government, } \\
\text { Report on } \\
\text { the } \\
\text { Accountabili } \\
\text { ty of the } \\
\text { Regional } \\
\text { Head to the } \\
\text { Regional } \\
\text { People's } \\
\text { Legislative } \\
\text { Assembly, } \\
\text { and } \\
\text { Information } \\
\text { on the } \\
\text { Report on } \\
\text { the Implementati } \\
\text { on of } \\
\text { Regional } \\
\text { Government } \\
\text { to the } \\
\text { Community }\end{array}$ & $\begin{array}{l}\text { Act Number } 32 \\
\text { the Year } 2004 \\
\text { regarding } \\
\text { Regional } \\
\text { Government } \\
\text { (replaced by Act } \\
\text { Number 23 the } \\
\text { Year 2014 on } \\
\text { Regional } \\
\text { Government } \\
\text { Becomes }\end{array}$ & $\begin{array}{l}\text { the basis for } \\
\text { Conducting } \\
\text { coaching in } \\
\text { the } \\
\text { organization } \\
\text { Provincial } \\
\text { and Regency } \\
\text { / Municipal }\end{array}$ & $\begin{array}{lr}\text { Governments } \\
\text { Provincial and } \\
\text { Regency } \\
\text { Municipal } \\
\text { Governments }\end{array}$ & $\begin{array}{l}\text { 1.1. End of } \\
\text { Fiscal } \\
\text { Year; } \\
\text { and } \\
\text { 2. End of } \\
\text { the term } \\
\text { of office. }\end{array}$ & $\begin{array}{l}\text { President, } \\
\text { DPRD }\end{array}$ & $\begin{array}{l}\text { LPPD: } \\
\text { Decentraliza } \\
\text { tion Affairs; } \\
\text { Co- } \\
\text { Administrati } \\
\text { on Tasks and } \\
\text { General } \\
\text { Duties } \\
\text { LKPJ:Decen } \\
\text { tralization } \\
\text { Affairs, Co- } \\
\text { Administrati } \\
\text { on Tasks, } \\
\text { and General } \\
\text { Government } \\
\text { Duties }\end{array}$ \\
\hline $\begin{array}{l}\text { Regulation } \\
\text { of the } \\
\text { Minister of } \\
\text { Home } \\
\end{array}$ & $\begin{array}{l}\text { 1. Act Number } \\
32 \text { the Year } \\
2004 \text { regarding } \\
\text { Regional }\end{array}$ & $\begin{array}{l}1 . \\
\text { Consistency } \\
\text { between } \\
\text { policies and } \\
\end{array}$ & $\begin{array}{l}\text { 1. Provincial } \\
\text { Government; } \\
2 . \quad \text { City } \\
\text { Municipal } \\
\end{array}$ & Quarterly & $\begin{array}{l}\text { Ministers } \\
\text { and } \\
\text { Governors }\end{array}$ & $\begin{array}{l}1 . \quad \text { Control } \\
\text { and } \\
\text { evaluation of } \\
\text { regional }\end{array}$ \\
\hline
\end{tabular}




\begin{tabular}{|c|c|c|c|c|c|c|}
\hline Rules & $\begin{array}{l}\text { Original } \\
\text { Mandate }\end{array}$ & $\begin{array}{l}\text { Reporting } \\
\text { Objective }\end{array}$ & $\begin{array}{l}\text { Subject } \\
\text { Objective }\end{array}$ & Timing & User & Indicator \\
\hline $\begin{array}{l}\text { Affairs of } \\
\text { the Republic } \\
\text { of Indonesia } \\
\text { Number 54 } \\
\text { the Year } \\
2010 \\
\text { concerning } \\
\text { the } \\
\text { Implementati } \\
\text { on of } \\
\text { Government } \\
\text { Regulation } \\
\text { Number } 8 \\
\text { the Year } \\
\text { 2006 } \\
\text { concerning } \\
\text { Stages, } \\
\text { Procedures } \\
\text { for } \\
\text { Formulating, } \\
\text { Controlling } \\
\text { and } \\
\text { Evaluating } \\
\text { the } \\
\text { Implementati } \\
\text { on } \\
\text { Regional of } \\
\text { Developmen } \\
\text { t Plans }\end{array}$ & $\begin{array}{l}\text { Government } \\
\text { (replaced by } \\
\text { Undang- Law } \\
\text { Number } 23 \text { the } \\
\text { Year 2014 on } \\
\text { Regional } \\
\text { Government;2. } \\
\text { Government } \\
\text { Regulation No. } \\
8 / 2006 \text { on } \\
\text { Stages, } \\
\text { Procedures for } \\
\text { Formulation, } \\
\text { Control, and } \\
\text { Evaluation of } \\
\text { Implementation } \\
\text { of Regional } \\
\text { Development } \\
\text { Plans }\end{array}$ & $\begin{array}{l}\text { implementati } \\
\text { on and } \\
\text { outcomes of } \\
\text { regional } \\
\text { development } \\
\text { plans; } \\
2 . \\
\text { Consistency } \\
\text { between } \\
\text { RPJPD and } \\
\text { RPJPN and } \\
\text { national } \\
\text { RTRW; } \\
3 . \\
\text { Consistency } \\
\text { between } \\
\text { RPJMD and } \\
\text { RPJPD and } \\
\text { regional } \\
\text { RTRW; } \\
4 . \\
\text { Consistency } \\
\text { between } \\
\text { RKPD and } \\
\text { RPJMD; } \\
\text { and5. } \\
\text { Compliance } \\
\text { between } \\
\text { economic } \\
\text { development } \\
\text { outcomes } \\
\text { and } \\
\text { predetermine } \\
\text { d } \\
\text { performance } \\
\text { indicators. }\end{array}$ & Governments & & & $\begin{array}{l}\text { development } \\
\text { planning } \\
\text { policies; } \\
2 \text {. Control } \\
\text { and } \\
\text { evaluation of } \\
\text { the } \\
\text { implementati } \\
\text { on of } \\
\text { regional } \\
\text { development } \\
\text { plans; and } \\
3 \text {. } \\
\text { Evaluation } \\
\text { of the results } \\
\text { of the } \\
\text { regional } \\
\text { development } \\
\text { plan. }\end{array}$ \\
\hline $\begin{array}{l}\text { Ministerial } \\
\text { regulation } \\
\text { Utilization of } \\
\text { State } \\
\text { Apparatus } \\
\text { Bureaucratic } \\
\text { Reform of } \\
\text { the Republic }\end{array}$ & $\begin{array}{l}\text { President } \\
\text { Nornox's } \\
\text { Regulation. } 29 \\
\text { years } 2014 \\
\text { On Performance } \\
\text { Accountability } \\
\text { System of } \\
\text { Government } \\
\text { Agencies } \\
\end{array}$ & $\begin{array}{l}1 . \quad \text { As a } \\
\text { concrete } \\
\text { manifestatio } \\
n \text { of } \\
\text { commitment } \\
\text { between the } \\
\text { recipient and } \\
\text { the trustee to } \\
\text { improve the }\end{array}$ & $\begin{array}{l}\text { All Government } \\
\text { Agencies }\end{array}$ & $\begin{array}{l}\text { Measurem } \\
\text { ent: Every } \\
\text { three } \\
\text { months } \\
\text { (quarter) }\end{array}$ & $\begin{array}{l}\text { Government } \\
\text { Agencies } \\
\text { (OPD) }\end{array}$ & $\begin{array}{l}\text { Output and } \\
\text { Outcome } \\
\text { took from } \\
\text { Key } \\
\text { Performance } \\
\text { Indicators } \\
\text { (IKU). IKU } \\
\text { becomes a } \\
\text { reference in }\end{array}$ \\
\hline
\end{tabular}




\begin{tabular}{|c|c|c|c|c|c|c|}
\hline Rules & $\begin{array}{l}\text { Original } \\
\text { Mandate }\end{array}$ & $\begin{array}{l}\text { Reporting } \\
\text { Objective }\end{array}$ & $\begin{array}{l}\text { Subject } \\
\text { Objective }\end{array}$ & Timing & User & Indicator \\
\hline $\begin{array}{l}\text { of Indonesia } \\
\text { Number 53 } \\
\text { the Year } \\
2014 \\
\text { About } \\
\text { Performance } \\
\text { Agreement } \\
\text { Technical } \\
\text { Guidelines, } \\
\text { Performance } \\
\text { ReportingM } \\
\text { oreover, } \\
\text { Procedures } \\
\text { for Review } \\
\text { of } \\
\text { Performance } \\
\text { Reports } \\
\text { Government } \\
\text { agencies }\end{array}$ & & $\begin{array}{l}\text { integrity, } \\
\text { accountabilit } \\
\text { y, } \\
\text { transparency } \\
\text { performance } \\
\text { of the } \\
\text { Apparatus; } \\
\text { 2. Creating a } \\
\text { personnel } \\
\text { standard;3. } \\
\text { As the basis } \\
\text { for the } \\
\text { assessment } \\
\text { of the } \\
\text { success/failu } \\
\text { re of the } \\
\text { achievement } \\
\text { of the } \\
\text { organization' } \\
\text { s goals and } \\
\text { objectives } \\
\text { and as the } \\
\text { basis for } \\
\text { pricing and } \\
\text { sanctions; } \\
4 \text {. As a basis } \\
\text { for providers } \\
\text { to conduct } \\
\text { monitoring, } \\
\text { Evaluation } \\
\text { and supervision } \\
\text { on the } \\
\text { development } \\
\text { /progress of } \\
\text { the } \\
\text { recipient's } \\
\text { performance } \\
\text {; } 5 . \text { As the } \\
\text { basis for the } \\
\text { performance } \\
\text { of employee } \\
\text { performance } \\
\text { targets, All } \\
\text { Government }\end{array}$ & & & & $\begin{array}{l}\text { the } \\
\text { preparation } \\
\text { of RPJMD }\end{array}$ \\
\hline
\end{tabular}




\begin{tabular}{|l|l|l|l|l|l|l|}
\hline Rules & $\begin{array}{l}\text { Original } \\
\text { Mandate }\end{array}$ & $\begin{array}{l}\text { Reporting } \\
\text { Objective }\end{array}$ & $\begin{array}{l}\text { Subject } \\
\text { Objective }\end{array}$ & Timing & User & Indicator \\
\hline & $\begin{array}{l}\text { Agencies } \\
\text { Measuremen } \\
\text { ts: Every } \\
\text { thee months } \\
\text { (quarter) } \\
\text { Government } \\
\text { Agencies } \\
\text { (OPD) } \\
\text { Output and } \\
\text { Outcome } \\
\text { taken from } \\
\text { Key } \\
\text { Performance } \\
\text { Indicators } \\
\text { (IKU). IKU } \\
\text { becomes a } \\
\text { reference in } \\
\text { the } \\
\text { preparation } \\
\text { of RPJMD }\end{array}$ & & & & \\
& & & & \\
& & & & \\
& & & & \\
\end{tabular}

Based on the table above, it can be analyzed that there are various types of monitoring and evaluation following performance reporting was done and arranged at the same time. The reporting has a variety of formats with relatively similar types of monitoring and evaluation. Overall development monitoring and evaluation activities in the area also involve the Regional Government Organization (OPD) of the Regional Government. The monitoring and evaluation also measure the performance of programs/activities undertaken by the Regional Government. The distinction only occurs to the intended party in the reporting.

This, of course, requires resources that are excellent both material and non-material wise. It also affects the budget allocation is not small. So the problems arising are as follows:

1. Material Inefficiency.

In the implementation of development performance, monitoring cannot be separated from the need for coordination and inspection of the field. This, of course, requires a budget that is not small either for the needs of coordination in the form of meetings or field visits. Not a lot of budget allocated to support the implementation of the activities of the preparation of each activity.

2. Non-Material Inefficiency

Different types of reporting performance with almost the same period require energy and time that is not small, which results in the use of reports as a follow-up improvement of development planning to be not optimal.

Based on an analysis of the existence of various legislations on reporting of monitoring and evaluation results, this can be a form of hyper-regulation [6]. Conditions, according to Ann Seidman [7], caused the government to compete in translating various policies into legislation. Therefore, a unification of the various laws and regulations is required. 
Unification, according to Big Indonesian Dictionary defined as unification or made things uniform.

Unification can be done by covering the element:

1. Objectives Monitoring and evaluation are a measurement of success or failure of development, of a material to conduct guidance to agencies and as materials to prepare for future development planning.

2. Time of monitoring and evaluation shall consist of quarterly, semester, yearly, and end of the tenure of Head of Region.

3. The subjects conducting the monitoring and evaluation shall cover all witnesses both at the Provincial and District/City levels.

4. The monitoring and evaluation component consists of indicators that are in the OPD program/activities.

All reports of monitoring and evaluation results can ultimately be utilized by all government agencies whether Minister, DPRD, Governor or Regent/ Mayor. The most important aspect of monitoring and evaluation is the utilization and use of monitoring and evaluation results for future development planning, according to Holte-McKenzie at.al. Monitoring and evaluation (M\&E) is a recognized management practice that allows for learning and change when implemented regularly [9]. Appropriate accuracy in the use of monitoring and evaluation results will minimize the gap in achieving development targets.

\section{Conclusion}

Based on the analysis above, it can be concluded as follows:

1. Monitoring and evaluation of development are still not effective and efficient due to monitoring and evaluation carried out repeatedly in one reporting period.

2. Unification of laws and regulations concerning monitoring and evaluation is necessary because it will be more effective and efficient in carrying out monitoring and evaluation.

\section{References}

[1] A. Purwadi, "Harmonisasi Pengaturan Perencanaan Pembangunan Antara Pusat Dan Daerah Era Otonomi Daerah,” Jurnal Perspektif, Vol. 18, No.2, 86 - 95, 2013

[2] Sjafrizal,Perencanaan Pembangunan Daerah Dalam Era Otonomi, Jakarta: RajaGrafindo Persada, 2016

[3] S. Wignjosoebroto, Hukum, Paradigma, Metode dan Masalah, Jakarta: Elsam dan Huma, 2002

[4] S. Soerjono, PengantarPenelitian Hukum, Jakarta: PenerbitUniversitas Indonesia, 1984

[5] A. N. Jamaluddin, Sosiologi Pembangunan, Bandung: Pustaka Setia, 2016

[6] A, D. Bayu, PerkembanganPembentukanUndang - Undang di Indonesia, Jakarta: Konstitusi Press, 2013.

[7] C. Ansell, "The Networked Polity: Regional Development in Western Europe.”Governance, Vol. 13, No. 2, p. 279-291. 2000.

[8] M.Holte-McKenzie, S. Forde, \&S. Theobald, "Development of a participatory monitoring and evaluation strategy." Evaluation and Program Planning, Vol. 29, No. 4, p. 365-376. 2006

[9] Rodríguez-Pose, A. “Do Institutions Matter for Regional Development?".Regional Studies, 47(7),2013. p. 1034-1047. 
